\title{
IFRS als krachtproef voor het accountantsberoep
}

\section{Martin Hoogendoorn}

De invoering van de verplichte toepassing van de International Financial Reporting Standards (IFRS) in de geconsolideerde jaarrekeningen van alle beursgenoteerde ondernemingen in Europa is één van de meest ingrijpende vernieuwingen in de verslaggeving ooit. Vanaf 2005 zullen

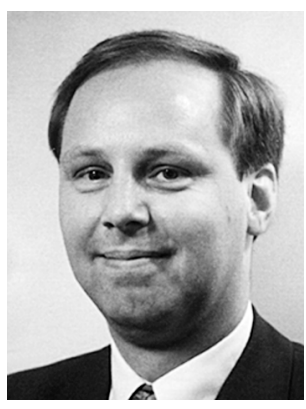
zo'n 7.000 tot 9.000 ondernemingen in Europa met de nieuwe eisen worden geconfronteerd. Straks geen lokale regels meer, maar voor heel Europa dezelfde eisen. En die eisen zijn geen grootste gemene deler van de huidige lokale regels, maar gericht op het hoogst mogelijke niveau van transparantie.

Nederlandse ondernemingen hebben een zeker voordeel ten opzichte van buitenlandse bedrijven. De Raad voor de Jaarverslaggeving (RJ) is immers al vele jaren terug begonnen om IFRS (toen nog IAS) zoveel mogelijk over te nemen als 'Dutch GAAP', zij het met enkele vrijstellingen en afwijkingen. De Nederlandse onderneming die nu al volledig de RJ-Richtlijnen volgt, hoeft niet echt veel te veranderen. Behalve dan de twee belangrijke standaarden die nog niet zijn ingevoerd, IAS 19 over pensioenen (de Richtlijn 2.71 is nu net verschenen met ingangsdatum 2005) en IAS 39 over financiële instrumenten (implementatie is op dit punt achterwege gebleven omdat deze IAS nogal aan verandering onderhevig is). Maar voor het overige lijkt het dat de invoering voor Nederlandse ondernemingen niet erg ingrijpend hoeft te zijn.

Prof. Dr. M.N. Hoogendoorn RA is partner bij Ernst \& Young Accountants, hoogleraar Externe verslaggeving aan de Erasmus Universiteit Rotterdam, en voorzitter van de Raad voor de Jaarverslaggeving.
Toch leert de praktijk anders. Het belangrijkste verschil betreft niet zozeer de inhoud van de regels, maar vooral de strikte mate van toepassing daarvan. De RJRichtlijnen hebben geen status van wet. Afwijkingen zijn toegestaan indien daarvoor goede redenen bestaan. Allesbepalend voor de jaarrekening is het inzichtsvereiste, dat ertoe kan leiden dat van de regels wordt afgeweken. Dit is 'principles-based accounting' in optima forma.

Van de specifieke IFRS-regels mag echter vrijwel nooit worden afgeweken. Er is een zeer beperkte mogelijkheid tot een zogenaamde 'true and fair override', waarin vanwege het getrouwe beeld een bepaalde regel niet strikt wordt nageleefd, maar de algemene verwachting is dat dit een nauwelijks voorstelbare optie is. Daarmee is voor Nederlandse ondernemingen in belangrijke mate sprake van een overgang van 'principles-based accounting' naar 'rules-based accounting', nog niet zo vergaand als in de Verenigde Staten, maar toch wel heel dicht daarbij in de buurt. En dat zal wennen zijn.

Ook voor het accountantsberoep zal de introductie van IFRS een krachtproef worden. Immers, indien op een enkel onderdeel niet is voldaan aan IFRS, kan geen onvoorwaardelijke goedkeurende verklaring worden gegeven. Zelfs indien, naar de opvatting van zowel onderneming als accountant, volledig is voldaan aan het inzichtsvereiste of het getrouwe beeld. De attitude in een 'rules-based' systeem is geheel anders dan in een 'principles-based' systeem. Ook indien het niet navolgen van de regels geen opzet is van de onderneming, maar een gevolg is van een gebrek aan beschikbare informatie, past geen onvoorwaardelijke goedkeurende verklaring. Natuurlijk geldt ook onder IFRS het materialiteitsbeginsel, maar dat kan niet dienen als vangnet.

De consequenties van een niet-goedkeurende verklaring kunnen groot zijn. Immers, een onderneming is verplicht, ten behoeve van zijn beursnotering, om 
IFRS toe te passen. Het niet kunnen of willen voldoen aan die verplichting kan daarom vervelende gevolgen hebben: vermindering van het vertrouwen, daling van de beurskoers, mogelijk schorsing van de beursnotering. De druk op de accountant om, zeker bij relatief geringe gebreken, de jaarrekening toch volledig goed te keuren, zal daarom fors kunnen zijn.

Kan de accountant deze druk aan? Als het antwoord daarop 'nee' zou zijn, dan betekent dat naar mijn mening het einde van de uitvoering van de wettelijke accountantscontrole op de huidige wijze. De accountant is druk bezig om op te krabbelen en te werken aan het herstel van het vertrouwen. Enige ruis bij de invoering (en latere toepassing) van IFRS doorbreekt dit proces. Ik heb de indruk dat de grote accountantsorganisaties zich hier ten volle van bewust zijn. Er zijn ook andere institutionele ontwikkelingen die de accountant geen enkele onderhandelingsruimte laten. Dit betreft vooral de introductie van het toezicht, zowel op financiële verslaggeving als op accountants, beide in Nederland onder te brengen bij de AFM. Maar ook de belangrijkere rol die analisten zullen spelen. Veel beter dan voorheen kunnen de internationaal beste analisten grip krijgen op de verslaggeving van Europese beursfondsen, omdat immers IFRS bij hen bekend is en de onderlinge vergelijkbaarheid sterk wordt verbeterd. Mogelijke gebreken in de verslaggeving zullen naar verwachting eerder aan het licht worden gebracht. De accountant zal zich, door de introductie van IFRS, meer dan ooit in een kwetsbare positie bevinden.

Er is nog een ander nieuw element waardoor de accountant extra kwetsbaar is. De Grote Vier werken onder gemeenschappelijke naam. De ondergang van Arthur Andersen heeft aangetoond hoe kwetsbaar dat is. De rotte appel tast de hele fruitmand aan. Dat zou in Europa ook kunnen gebeuren. Collega's in andere landen die het minder nauw zouden nemen leveren een gevaar op voor het hele beroep. Zeker in landen waar een meer ontspannen cultuur bestaat, en de ondernemingen niet tijdig zijn begonnen met hun voorbereidende werkzaamheden, zou een strikte houding van de buitenlandse collega's tot vele niet-goedkeurende verklaringen moeten leiden. Met alle gevolgen van dien.

De introductie van IFRS wordt een spannende periode. Het is een krachtproef voor het accountantsberoep. Het is misschien wel een kwestie van overleven of niet. 